\title{
The Impact of CAGE Institutional Distances and Motivations for Internationalization on the Brazilian Foreign Direct Investment Outflows
}

\author{
Manuel Portugal Ferreira ${ }^{1,2,+(1)}$ \\ ${ }^{1}$ Universidade Nove de Julho, São Paulo, SP, Brazil \\ ${ }^{2}$ Instituto Politécnico de Leiria, Portugal \\ Marcelo Braga Falcão $3, \Omega$ (C) \\ ${ }^{3}$ Universidade Nove de Julho, São Paulo, SP, Brazil
}

\section{ABSTRACT}

In this study, we have analyzed the influence of institutional distances and strategic motivations for internationalization on Brazilian foreign direct investment (FDI). We suggest that institutional differences, between Brazil and the host country, measured with Ghemawhat's (2001) CAGE typology, have a negative impact on FDI flows. However, we propose that the market-seeking and strategic asset-seeking motivations (e.g., new knowledge acquisition) moderate the impact of institutional differences on investment decisions by reducing the impact of the institutional distances between countries on investment decisions.

Keywords: Institutional Distance, Foreign Direct Investment, CAGE, Brazil.

\section{INTRODUCTION}

Countries differ markedly in their framework of institutions and the development and sophistication of institutions (NORTH, 1990). These differences create opportunities for firms, such as foreign multinationals seeking to enter, but also difficulties in operating in foreign markets. Generally, the literature points out that institutions are country-specific and company strategies are, at least in part, determined by the institutions of their country of origin, by the country of destination of the investments and by the differences between the institutions of the countries of origin and destination (PENG; WANG; JIANG, 2008; BERRY; GUÍLLEN; ZHOU, 2010). The literature also points out that under conditions of greater institutional distance firms restrict their investments in response to risks and uncertainties (BERRY; GUÍLLEN; ZHOU, 2010; GATIGNON; ANDERSON, 1988). That is, the differences between countries generate uncertainty, asymmetry of information, additional administrative costs and difficulties in transferring knowledge to and from foreign subsidiaries (KOSTOVA; ZAHEER, 1999; CONTRACTOR et al., 2014). Thus, in internationalization for more institutionally similar markets, it is easier to do business (KOSTOVA; ZAHEER, 1999: KOSTOVA; ROTH, 2002) than in entries in more different markets. Therefore, differences between countries need to be taken into account in foreign investment
Corresponding author:

† Universidade Nove de Julho, São Paulo, SP, Brazil; Instituto Politécnico de Leiria, Portugal E-mail: manuel.portugal.ferreira@gmail.com $\Omega$ Universidade Nove de Julho, São Paulo, SP, Brazil

E-mail: mfalcaox@gmail.com

Received: 11/14/2016.

Revised: 08/01/2017.

Accepted: 05/04/2018

Published Online: 01/30/2019.

DOI: http://dx.doi.org/10.15728/bbr.2019.16.2.4 
decisions (GHEMAWAT, 2001; DOW; KARUNARATNA, 2006). However, the literature is less exhaustive in considering how firms are sensitive to institutional differences according to the strategic focus desired for the foreign country. That is, in spite of the determinism entailed in institutional aspects of the environment, it is necessary to consider how firms that seek to broaden markets or firms that seek to access to strategic resources are differently influenced by the institutional pressures and differences across countries.

In the last two decades there has been a notable international growth of firms from emerging countries, including those in Latin America - termed as multilatinas (CUERVOCAZURRA; GENC, 2008) or "Global Latinas" (CASANOVA, 2009). Some well-known examples include Cemex, Arcor, Embraer, Natura, Bradesco, Falabella, Grupo AJE, Belcorp, among others, which have achieved remarkable success in their domestic markets and sought a more aggressive expansion on a global scale (BCG, 2014). The expansion of these emerging multinationals, or multilatinas, has been associated with two fundamental reasons: the search for markets and the search for strategic resources, or the upgrade of knowledge and technologies (CASANOVA, 2009a, 2009b; CUERVO-CAZURRA, 2008; STAL; CAMPANÁRIO, 2010) which cannot be found in their countries of origin (FERREIRA, 2008; CUERVO-CAZURRA, 2016; BUCKLEY et al., 2007). For example, the firms Natura and Politec, invested abroad to access scarce, and not easily transferable, knowledge assets. While Natura invested in France in search of market knowledge and Research and Development (R\&D), Politec acquired a company in the US to improve its ability to compete in the North American market (OTALORA; CASANOVA, 2012).

Institutional theory makes it possible to understand the differences between countries in their various facets, but it also helps to explain the motivations for international expansion. On the one hand, the inefficiencies in the domestic market (CONTI; PARENTE; VASCONCELOS, 2016) can push firms to seek other markets (larger, more stable or more attractive) that Cuervo-Cazurra, Narula and Un (2015) termed escapism. Institutional theory also helps understanding that the internationalization of some firms may be a manifestation of the search for new knowledge that can only be accessed locally - that is knowledge that evolves differently as a result of the country's technological trajectories and of its institutional framework (NORTH, 1990; PENG; WANG; JIANG, 2008; BERRY; GUÍLLEN; ZHOU, 2010). To evaluate the institutional environment and measure how institutional differences influence the actions of individuals and firms, Pankaj Ghemawat (2001) created the CAGE taxonomy - which is the acronym for Cultural, Administrative, Geographic and Economic distances that separate countries. Other authors, such as North (1990) refer to the formal and informal dimensions. Berry, Guíllen and Zhou (2010) proposed to disaggregate the institutional distance construct into a set of multidimensional measures, including economic, financial, political, administrative, cultural, demographic, knowledge and global dimensions, as well as geographical distance to accommodate the different dimensions in which countries differ from one another. The CAGE taxonomy by Ghemawat (2001) has the advantage of being simpler and, unlike most existing approaches, considers the bilateral attributes of pairs of countries, besides the unilateral attributes of each country, and contemplates a sufficiently wide range of institutional diversities.

In this study, we analyzed the influence of institutional distances CAGE (GHEMAWAT, 2001) on the Brazilian FDI and how the strategic motivations to search for new markets and search for strategic resources can change the way institutional differences across countries determines foreign investment. The statistical study uses secondary data of the Brazilian foreign direct investment outflows with analyzes using multivariate regression. We suggest that institutional differences between countries may exert a negative influence on FDI, but that it is also necessary to consider the role of the strategic motivations, and their direct 
BBR

16,2

and moderating effects, on firms' investment decisions. For example, it is possible that strategic motivations may reduce the sensitivity of investment decisions to institutional uncertainties. This is especially relevant in the case of Brazil for three foundational reasons. First, Brazilian firms are still relatively inexperienced in conducting foreign investment operations (FLEURY et al., 2013). Second, given the inefficiencies of the Brazilian domestic market, the reason for escapism proposed by Cuervo-Cazurra et al. (2015) seems to be more emphatic than it would probably be for firms from developed countries. Third, studies on emerging economies are very concentrated in the countries and firms from Southeast Asia, especially China, and far less focused on the Latin American firms (STAL; CAMPANÁRIO, 2010).

This study has a conceptual contribution to the international business and strategy area. Mathews (2006a) brings Buckley's (2002) analysis about the field of study of international business (IB), which suggested that the international business research agenda of the twentieth century went through three main phases: to explain the flows of FDI (1960-1970), explain the strategy and organization of multinationals from developed countries (19701990), and the understanding of the development of the process of internationalization of firms and globalization (1980-2000), but pondering that the distinction made between firms from developed and emerging countries is lacking in this debate, and proposes the following question for the continuity of research in the 21 st century: "What explains the current success of the internationalization strategies of firms from emerging countries?" Thus, it is important to combine the influence of the institutional environment with businesslevel strategies, a deterministic element with the orientation and choice of the firms. This is achieved with our proposal to analyze the motivations proposed by Dunning (2003) in addition to institutional theory in order to evaluate the strategy of internationalization of multilatinas and more specifically, Brazilian firms.

There is, therefore, a contribution in addition to other studies that have examined the influence of institutional aspects on FDI (e.g., Bénassy-Quéré et al., 2007), or institutional distance (Cezar \& Escobar, 2015) and the specific endowment of natural resources in least developed countries in FDI (Aleksynska \& Olena Havrylchyk, 2013), of the influence of institutional differences between country of origin and destination and the uncertainty generated by firms adopting strategies of isomorphism (Salomon \& Wu, 2012). In this study, we propose strategic motivations as an essential moderator of the institutional differences between countries. That is, we contrast the institutional determinisms with the strategic responses of the firms.

This study is organized in four parts. First, we review the relevant literature and present the arguments that support the hypotheses. In the second part, we describe the method including sample and variables. We then reveal the results of the statistical tests. In part four, we formulated a comprehensive discussion and included suggestions for future research and limitations.

\section{LITERATURE REVIEW AND HYPOTHESES}

National institutions have the essential role of ensuring the efficient and effective functioning of market mechanisms, reducing transaction costs and risks (NORTH, 1990). The quality of institutions is an important determinant of FDI activity, in particular for least developed countries (BLONINGEN, 2005), where weak property protection increases the risks of expropriation, corruption increases costs and creates unpredictability, and poor infrastructure reduces profitability and reduces the attractiveness of countries to FDI (BLONINGEN, 2005). 


\subsection{INFLUENCE OF INSTITUTIONAL DISTANCE IN FDI}

The way institutions vary across countries - or institutional distance need to be considered.

The difference between two institutional environments is called institutional distance and reflects, for example, the additional risks for the operation of a foreign company (KOSTOVA; ZAHEER, 1999). Variations are especially relevant because organizations must adapt to local rules, norms and beliefs (MEYER; ROWAN, 1977). Institutional distance influences the costs, risks and benefits of overseas investment (KOSTOVA; ZAHEER, 1999), and leads firms to delay or a distance to their investments (JOHANSON; VAHLNE, 1977). The institutional distance also influences the choice of locations and the way of entry abroad (for example, whether by greenfield investment or acquisition) (MEYER; ESTRIN, 2004).

The CAGE model, by Ghemawat (2001), is a typology of four institutional dimensions - Cultural, Administrative, Geographical and Economic - between countries, which allows characterizing the institutional environment of each country and measuring institutional distance between countries. The CAGE distances approach (GHEMAWAT, 2001) can explain the internationalization decisions, the choice of countries and the realization of foreign direct investment. Dimensions are briefly described below.

Cultural distance refers to cultural differences between countries that generate uncertainty and restrict the flow of information and knowledge between countries, increasing the cost of doing business (HOFSTEDE, 1980). The country's cultural attributes determine how firms interact (GHEMAWAT, 2001). Differences of religion, race, social norms and language, among others, are factors of cultural distance, with a potential impact on trade and investment. For example, trade and foreign investment between countries sharing a language (like Brazil and Portugal) tends to be greater than between countries with different languages (GHEMAWAT, 2001). Cultural proximity is then the promoter of FDI flows between countries.

Administrative distance can be interpreted as differences in formal and informal institutions between countries (GHEMAWAT, 2001). For example, countries that are part of an economic bloc (e.g.: Mercosul) and have similar political systems, create conditions that facilitate the operation for the firms of these countries, promoting the flows of FDI. Countries can create administrative distance through unilateral measures designed to protect national industries or natural resources, or to ensure national security (GHEMAWAT, 2001). The greater the administrative similarities, i.e., the smaller the administrative distance, the greater the probability that the subsidiaries of a company comply with the institutional requirements and norms of the country of destination, facilitating the realization of FDI (CAMPBELL; EDEN; MILLER, 2012).

Geographic distance comprises differences related to separation, or distance, between countries (GHEMAWAT, 2001), which influence the trade and investment flows between the countries (CAMPBELL; EDEN; MILLER, 2012). Firms tend to prefer to internationalize to closer countries because they incur lower costs (DOW, 2000). Increased costs of geographic distance discourage the realization of FDI.

Economic distance is related to the differences in the country's macroeconomic stability, investment policies, the level of openness to foreign capital, the availability of credit, levels of economic development between countries, and skilled labor (GHEMAWAT, 2001). Greater economic distance leads to greater uncertainty and perception of risk in internationalization (XU; SHENKAR, 2012). Countries differ in terms of the income level of the population (GDP per capita), rates of inflation, and the intensity of commercial transactions with the rest of the world (exports plus imports as a proportion of GDP). These indicators are important because they correlate with consumer purchasing power and preferences, macroeconomic 
BBR

16,2

158

stability and the openness of the economy to external influences. These factors have been identified as influencers, for example, the mode of entry into the foreign market and survival and performance of the company (BERRY; GUÍLLEN; ZHOU, 2010).

In short, considering the CAGE dimensions we formulate the following hypothesis:

Hypothesis 1. The CAGE Institutional distances - Cultural, Administrative, Geographic and Economic - between Brazil and a host country negatively influence the Brazilian FDI outflows to that country.

\subsection{Motivations FOR FDI}

John Dunning (1993) established four fundamental strategic motivations for FDI operations that he described as: FDI to search for new markets, FDI to search for resource, IDE to search for better efficiency and FDI to search for strategic assets. The two motifs that emerge as main in the literature, in the case of expansion of multinationals of emerging economies we find the search for market (CONTI et al., 2016) and the search for strategic resources (FERREIRA, 2008). First, to access a broader market. Conti, Parente and Vasconcelos (2016) argued that institutional weaknesses in domestic markets (CUERVOCAZURRA et al., 2015; CUERVO-CAZURRA, 2016) may lead firms to seek other markets that are larger, more stable, or more attractive for the population's income and consumption potential. As identified by UNCTAD (2006), the motivation to search for new markets is the most common type of strategy used by firms from emerging countries in their internationalization processes. Second, to access strategic resources that can compensate for their competitive disadvantages arising from the lack of strategic resources and capacity (CROSS; VOSS, 2008). Emerging multinationals can access more developed markets to absorb knowledge and skills that are not available in their domestic markets, result of the countries' own technological trajectory (DENG, 2009). Mathews (2006) on the Asian "dragon multinationals" relates how firms can internationalize through FDI even if they do not have substantial resources that could give them some kind of competitive advantage in the countries of destination.

\subsubsection{MARKET SEEKING MOTIVATIONS}

Market-seeking strategies seek to expand the consumer market. If in some cases it is possible to opt for export, in other cases it is necessary to establish commercial or production structures located in these markets (BUCKLEY et al., 2007; CROSS; VOSS, 2008). Several studies point to the growth of the search for new markets encouraging firms from emerging countries particularly to large markets (TAYLOR, 2002).

The limited size of the domestic market, or its saturation (GOUVEIA, 2007), the structure of demand and the weak growth potential of the market encourage firms to internationalize. In some cases it may be institutional inefficiencies, such as the deficiencies in the infrastructures that make difficult the service of the domestic market that drives the firms to internationalize (CUERVO-CAZURRA, 2016) For example, Brazilian software firms have explored different modes of entry into other markets, most starting by exporting their software, later with joint ventures, and arriving at the installation of subsidiaries through FDI (GOUVEIA, 2007), but there is also evidence that firms are increasingly rapidly undertaking FDI (PINTO et al., 2017) bypassing the intermediate steps listed in the gradualist school of Upsalla (JOHANSON; VAHLNE, 1977). 
Hypothesis 2. Market-seeking strategies positively influence Brazilian FDI outflows to another country.

\subsubsection{STRATEGIC RESOURCE SEEKING MOTIVATIONS}

Multinationals from emerging countries that invest in other countries seeking strategic resources, tend to seek technological know-how, brand image (foreign brands), management and marketing skills (BUCKLEY et al., 2007). These strategic resources allow emerging multinationals to build a structured set of competencies that support competitive advantages, product innovation and distribution channels. As explained by Cross and Voss (2008), emerging multinationals do not necessarily have the resources that can be exploited in foreign markets, which would make them, in fact, multinationals "without advantages". These multinational firms, therefore, invest in developed countries by adopting aggressive investment measures in order to acquire critical resources from mature multinationals to compensate for the "competitive disadvantages" (LUO; TUNG, 2007 , p. 481). The underlying reason is that many multinationals from emerging economies are "laggard" on the world economy scenario and, therefore, in order to be able to compete with developed market multinationals, need to invest in obtaining technological know-how, management and marketing skills and brand image (DUNNING, 2008). This argument reveals that, unlike multinationals from developed countries, emerging multinationals use internationalization to access strategic resources and upgrade, which it does not yet hold (MATHEWS, 2006a). That is, the internationalization of these firms is not based on the possession of pre-existing resources that can be exploited in the international expansion, as is the case with multinationals from developed countries.

Therefore, FDI decisions can be driven by driving factors - generated in the country of origin and which encourage national firms to seek internationalization - and attraction factors - based on existing opportunities and challenges in the target countries of investment (UNCTAD, 2012). After an initial period in the internationalization in which the emerging multinationals sought knowledge of how to operate in foreign markets, the second phase started being motivated to seek intangible assets such as patents. The acquisition of foreign technologies and brands is often, regarded as a shortcut to establishing the company as a quality manufacturer, internationally recognized for having a portfolio of state-of-theart technologies (CHILD; RODRIGUEZ, 2005). By acquiring new or complementary resources, firms improve their ability to compete globally (YIU; LAU; BRUTON, 2007; MAKINO; LAU; YEH, 2002). Some Latin American multinationals have used this strategy to create value abroad (CASANOVA, 2009a, b). For example, the Brazilian company Politec acquired the US company Sinergy to access the leading iris recognition technology that was not available in the Brazilian market (CASANOVA, 2009b).

The importance of investing in innovation hardly needs any justification (DAMANPOUR; WALKER; AVELLANEDA, 2009). Two issues concerning the importance of innovation for multinational enterprises in emerging economies deserve special attention. First, multinationals from emerging countries may not have the innovative ability to exploit new disruptive technologies compared to their rivals in developed economies (FLEURY; FLEURY; BORINI, 2013). Second, there is a significant gap in the capacity for innovation between multinational firms in emerging countries and their developed rivals, especially in high technology industries (FLEURY; FLEURY; BORINI, 2013). 
BBR

16,2

Hypothesis 3. Strategies resource seeking strategies influence positively Brazilian FDI outflows to another country.

\subsection{MODERATION OF THE MOTIVATIONS FOR INTERNATIONALIZATION IN THE RELATION BETWEEN CAGE AND FDI}

It is possible that the motivations for internationalization, and specifically the FDI (DUNNING, 1993), influence the negative relation between the institutional distances between the countries of origin and destination and the FDI. We propose that the motivations to search for markets and search for strategic resources have a moderating effect, attenuating the relation of the CAGE and FDI distance. Although Dunning (1993) has conceptualized other strategic motivations, in particular the search for efficiency and the search for resources, the search for markets and strategic resources seem to be related to a large part of the investment abroad by firms from emerging economies and by the multilatinas specifically.

Acquiring firms from developed countries is one way for emerging multinationals to gain new skills and knowledge (GUGLER; BRUNNER, 2007). Developed countries can offer two main advantages for emerging market firms: sophisticated strategic assets such as technology and brands (DENG, 2009; MAKINO; LAN; YEH, 2002; MATHEWS, 2006a,b), and a relatively more stable and favorable environment for business development (BROUTHERS; O'DONNELL; HADJIMARCOU, 2005). The competition emerging multinationals face in developed markets can generate learning opportunities with more sophisticated competitors, thereby improving their strengths and helping to overcome possible local institutional disadvantages (UNCTAD, 2004), facts which tend to attenuate the effect of CAGE distances on the decision of FDI.

Recent studies explain that FDI from emerging economies to developed destinations, are partly related to a form of "institutional escapism" (CUERVO-CAZURRA; GENC, 2008; WITT; LEWIN, 2007). Specifically, Witt and Lewin (2007), for example, suggest that the need for growth of firms in emerging economies is hampered by non-business-friendly institutions such as corruption, weak regulations, undeveloped property rights, ineffective government and insufficient financial markets, among others, creating significant loss opportunities. If these losses exceed the costs of opening a new domestic business and the cost related to the difficulties that firms find in other markets ("liability of foreignness"), Emerging economies can be targeted to seek to invest in developed economies (BOISOT; MEYER, 2008).

Hypothesis 4. Market seeking strategies reduce the influence of the CAGE institutional distances on FDI, such that FDI outflows will be less sensitive to institutional differences.

Hypothesis 5. Strategic resource seeking strategies reduce the influence of the CAGE institutional distances on FDI, such that FDI outflows will be less sensitive to institutional differences.

\section{METHOD}

Emerging economies have emerged as an important source of FDI abroad since the 1990s. For example, between 1980 and 2011, FDI outflows from emerging market multinationals increased by $20.7 \%$ and represented $31.8 \%$ of the world FDI in 2010 (FMI, 2013). Emerging multinationals invest not only in their neighboring, Asian or Latin American countries, for example, but also in developed economies (UNCTAD, 2004). Market constraints in emerging economies, for example in terms of purchasing power, are a determinant of internationalization (UNCTAD, 2004). 
The current evidence on the distribution of Brazilian FDI abroad shows some regional concentration (UNCTAD, 2013), with the bulk of FDI concentrated in the Americas (about $70 \%$ of Brazil's FDI in 2008), followed by Europe (29\%), with only $1 \%$ being for Asia, Africa and Oceania. Evolution shows a decrease in FDI in the Americas - from 86\% in 2001 to $70 \%$ in 2008 - and higher concentration of Brazilian FDI in Europe - from 12\% in 2001 to $29 \%$ in 2008 .

\subsection{VARIABLES}

The dependent variable is the average flow of Brazilian FDI to a foreign country between the years 2010-2012. Although the choice of the period is relatively random, we sought not to include the year 2008 in the context of "crisis" and subsequent years thereafter so that FDI flows had already stabilized, at least in comparison with previous years. The year 2012 was due to the year of this research. We used official data from the Coordinated Direct Investment Survey (CDIS) of the International Monetary Fund (IMF) (according to BUCKLEY, et al., 2007). For the Brazilian FDI in a given country we use the average value of the last 3 years in order to mitigate effects of non-characteristic "spikes", inflated by large transactions. Although it is a short period of only 3 years, it is possible that high-value point transactions influence the results. An average attenuates the influence of these occasional cases. The net FDI values in US dollars (therefore, deducted from the divestment carried out) were logarithmized by the natural logarithm.

\subsubsection{INDEPENDENT VARIABLES}

Institutional distance is the extent of the difference between two countries in terms of institutional context, which was expressed in the four CAGE dimensions - cultural, administrative, geographic and economic. The data for each of the dimensions were obtained on the internet page, through paid access, in CAGE comparator ${ }^{\mathrm{TM}}$ (GHEMAWAT, 2014). In this webpage Ghemawat provides the values for each of the items that make up the dimensions. To compute institutional distance, we used the formula by Kogut and Singh (1988), based on the Euclidean distances - in this case between Brazil and each of the recipient countries of Brazilian FDI, for each CAGE dimension. In this equation, Iij is the value for a country of destination, Iiu is the value for the country of origin (Brazil), Vi is the variance in each institutional dimension.

$$
I D_{j}=\sum_{i=1}^{4}\left\{\left(I_{i j}-I_{i u}\right)^{2} / V_{i}\right\} / 4
$$

The strategic motivations for the realization of FDI were determined as follows. Market seeking motivation was measured using the country's per capita GDP, using data obtained from the World Bank World Development Indicators (WDI, 2013). This measure seems adequate since higher yield has been used as indicator of greater attractiveness of the consumer market (ARTIGE, NICOLINI, 2005).

The strategic resource seeking motivation was measured as the availability of resources related to knowledge (patents) using data collected from the World Intellectual Property Organization (WIPO, 2013). We used the annual total of patent registrations in the country of destination (residents and non-residents) and we calculated the natural logarithm of the average patent over the 3-year period between 2010 and 2012 as a proxy for the motivation for pursuit of strategic resources as adopted by Buckley, et al. (2007), collected from the "World Intellectual Property Organization's statistics database" (WIPO, 2013). 
BBR

16,2

162

\subsubsection{CONTROL VARIABLES}

We have included three control variables at the country level: trade, inflation, and exchange rate, with data collected from the World Bank World Development Indicators 2013 and from IMF, 2017. Again, following the procedure in Buckley et al. (2007) we use the natural logarithm of the mean values of trade and inflation, transforming the 3-year average of 2010-2012 to mitigate effects of non-characteristic values. Table 1 summarizes the variables used.

Table 1. Description of variables.

\begin{tabular}{|c|c|c|c|}
\hline & Variables & Description & Data source \\
\hline $\begin{array}{l}\text { Dependent } \\
\text { variable }\end{array}$ & FDI & $\begin{array}{l}\text { Investment that involves a long-term } \\
\text { relationship and that reflects a lasting } \\
\text { interest and control by a domestic entity in } \\
\text { an economy (foreign direct investor or the } \\
\text { parent company). }\end{array}$ & FMI, 2013 \\
\hline \multirow{6}{*}{$\begin{array}{l}\text { Independent } \\
\text { variables }\end{array}$} & Cultural distance & $\begin{array}{l}\text { Differences between religious beliefs, } \\
\text { races, social norms and languages. }\end{array}$ & Ghemawat, 2014 \\
\hline & Administrative distance & $\begin{array}{l}\text { Differences in several factors, including } \\
\text { lack of colonial ties, lack of political and } \\
\text { monetary association, political hostility, } \\
\text { governmental policy, and institutional } \\
\text { weakness. }\end{array}$ & Ghemawat, 2014 \\
\hline & Geographic distance & $\begin{array}{l}\text { Differences in several factors, including } \\
\text { physical distance, lack of common } \\
\text { borders, lack of access to rivers and } \\
\text { seas, weaknesses in transport and } \\
\text { communication and climate. }\end{array}$ & Ghemawat, 2014 \\
\hline & Economic distance & $\begin{array}{l}\text { Differences in consumer income, cost } \\
\text { and quality of infrastructure and natural, } \\
\text { financial and human resources. }\end{array}$ & Ghemawat, 2014 \\
\hline & Search for markets & $\begin{array}{l}\text { Size of the market of the recipient country } \\
\text { (GDP per capita). }\end{array}$ & WDI, 2013 \\
\hline & $\begin{array}{l}\text { Search for strategic } \\
\text { resources }\end{array}$ & $\begin{array}{l}\text { Availability of resources related to } \\
\text { knowledge (patents). }\end{array}$ & WIPO, 2013 \\
\hline \multirow{4}{*}{$\begin{array}{l}\text { Control } \\
\text { variables }\end{array}$} & International trade & $\begin{array}{l}\text { The sum of exports and imports of goods } \\
\text { and services measured as a percentage of } \\
\text { gross domestic product. }\end{array}$ & WDI, 2013 \\
\hline & Inflation & $\begin{array}{l}\text { Inflation measured by the consumer } \\
\text { price index reflects the annual percentage }\end{array}$ & WDI, 2013 \\
\hline & & $\begin{array}{l}\text { change in the average cost to the } \\
\text { consumer of the purchase of a basket of } \\
\text { goods and services that can be corrected } \\
\text { or changed at specific intervals, for } \\
\text { example, yearly. }\end{array}$ & \\
\hline & Exchange rate & $\begin{array}{l}\text { Monetary value of the currency of one } \\
\text { country over another. }\end{array}$ & IMF, 2017 \\
\hline
\end{tabular}

Source: Authors' own elaboration. 


\subsection{SAMPLE}

The sample includes the countries that received inflows of Brazilian FDI in the period from 2010 to 2012, according to official data from the CDIS of the International Monetary Fund. The sample includes 55 countries (see Table 2).

Table 2. Brazilian FDI flows (2010-2012).

\begin{tabular}{lclc}
\hline Country & FDI (USD Millions) and \% & Country & FDI (USD Millions) and \% \\
\hline Austria & $47,033.48(37.5 \%)$ & Bolivia & $92.56(0.08 \%)$ \\
Netherlands & $19,929.98(15.9 \%)$ & Japan & $87.87(0.08 \%)$ \\
United States & $13,958.59(11.1 \%)$ & New Zealand & $72.38(0.07 \%)$ \\
Spain & $11,852.47(9.45 \%)$ & India & $64.65(0.06 \%)$ \\
Denmark & $6,634.41(5.29 \%)$ & Ecuador & $46.00(0.05 \%)$ \\
Argentina & $5,266.98(4.20 \%)$ & Mozambique & $43.44(0.04 \%)$ \\
Portugal & $2,801.33(2.23 \%)$ & El Salvador & $11.00(0.04 \%)$ \\
Hungary & $2,736.65(2.18 \%)$ & Australia & $8.00(0.010 \%)$ \\
Uruguay & $2,610.49(2.08 \%)$ & Israel & $6.00(0.06 \%)$ \\
Peru & $2,380.81(1.90 \%)$ & United Arab Emirates & $6.00(0.005 \%)$ \\
Canada & $1,336.63(1.06 \%)$ & Egypt & $5.00(0.004 \%)$ \\
United Kingdom & $1,184.00(0.95 \%)$ & Haiti & $5.00(0.004 \%)$ \\
France & $1,061.80(0.85 \%)$ & Czech Republic & $4.70(0.004 \%)$ \\
Colombia & $920.50(0.73 \%)$ & Libya & $3.00(0.0024 \%)$ \\
Venezuela & $841.44(0.68 \%)$ & Russia & $3.00(0.0024 \%)$ \\
Chile & $762.96(0.61 \%)$ & Cuba & $2.00(0.002 \%)$ \\
Mexico & $756.22(0.60 \%)$ & Malaysia & $2.00(0.002 \%)$ \\
Paraguay & $396.81(0.31 \%)$ & Mali & $2.00(0.002 \%)$ \\
Ireland & $387.53(0.32 \%)$ & Romania & $2.00(0.002 \%)$ \\
Angola & $382.09(0.31 \%)$ & Turkey & $2.00(0.002 \%)$ \\
Belgium & $381.69(0.31 \%)$ & Malta & $1.92(0.002 \%)$ \\
Italy & $283.88(0.23 \%)$ & Croatia & $1.00(0.001 \%)$ \\
Switzerland & $219.00(0.18 \%)$ & Nicaragua & $1.00(0.001 \%)$ \\
Namibia & $215.65(0.17 \%)$ & Oman & $1.00(0.001 \%)$ \\
Germany & $188.41(0.15 \%)$ & Guiney & $0.46(0.0004 \%)$ \\
Slovakia & $124.32(0.10 \%)$ & Finland & $0.32(0.0004 \%)$ \\
China & $111.00(0.09 \%)$ & Poland & $0.17(0.0001 \%)$ \\
Dominican Rep. & $103.14(0.09 \%)$ & & \\
Source:Awho) &
\end{tabular}

Source: Authors' own elaboration.

Due to the financial nature of the investments, we excluded from the sample destinations considered as tax havens according to Brazilian legislation, so as not to mask the motivations behind foreign direct investment from Brazil. We ought to highlight that by excluding tax havens, we are not excluding effective foreign direct investment, but only capital displacement. 
BBR

16,2

164

\section{RESULTS}

Table 3 presents the means and standard deviation of the variables and their correlation. The correlations are not high and do not show any problems of multicollinearity. The Variance Inflation Factor (VIF) are well below the acceptable level of 10 (NETER; WASSERMAN; KUTNER, 1985), confirming that there are no problems of multicollinearity.

Table 4 presents the results of the hypotheses tests. Model 1 includes the control variables. Models 2 to 5 test the four institutional distances CAGE. Models 6 and 7 include the two strategic motivations, and models 8 to 15 test the moderations. Model 16 is the complete model.

Model 2 tests the existence of a negative effect of cultural distance on the Brazilian FDI. A negative and significant coefficient $(\beta=-0.920, \mathrm{p}<0.01)$ confirms the negative effect, so that Brazilian firms tend to perform less FDI operations in countries that are culturally more distant from Brazil. This result may be evidence of the relatively small experience of Brazilian firms in internationalizing themselves and of the difficulty of operating in culturally different contexts. Model 3 does not confirm an effect of the administrative distance on the Brazilian FDI. Model 4 shows a significant negative coefficient $(\beta=-0.501, p<0.01)$ for the geographic distance, confirming that the greatest geographical distance between Brazil and the foreign country is a barrier to the realization of Brazilian FDI. It is possible that infrastructural inefficiencies contribute to this result by hindering relations between the parent company in Brazil, and overseas subsidiaries (GHEMAWAT, 2001). Some examples include the deficiencies in communications and the internet that hinder communication and reporting relationships, and the deficiencies in the physical infrastructures of transportation and airports. Finally, model 5 does not confirm the predicted negative effect of the economic distance on the Brazilian FDI. Perhaps an explanation is found in the approach by Conti, Parente and Vasconcelos (2016), that have suggested that differences between countries may lead firms to seek other markets (larger, more stable or more attractive) and by Ghemawat (2003).

Model 6 tests hypothesis 2 on the effect of the market seeking motivation on the Brazilian FDI. A positive and significant coefficient $(\beta=1.289, \mathrm{p}<0.01)$ confirms larger FDI flows to countries that have more attractive markets. Market seeking motivations underlying the FDI by emerging market firms has already been noted by, for instance, Taylor (2002). There are several reasons for this type of FDI, which replaces or complements pre-existing export flows, highlighting the need for greater consumer proximity and improvement of commercial assets abroad such as marketing channels and brands (DUNNING, 1993).

Model 7 tests hypothesis 3 on the influence of a strategic resource seeking motivation that is, for internationalizing through FDI to technologically more sophisticated countries. A positive and significant coefficient $(\beta=0.284, \mathrm{p}<0.05)$ confirms that there is a positive effect of a strategic resource seeking nature for the Brazilian FDI. This evidence is interesting and perhaps better understood when we consider that a part of the promotion policy of Brazilian industry supported by the BNDES sought to leverage technological skills (CASANOVA, 2009a,b).

Models 8 to 11 test hypothesis 4 on the moderating effect of market seeking motivation on the relationship between CAGE and FDI distance. The coefficients are not significant, and thus we cannot confirm the proposed moderating effect. This result is interesting but perhaps not completely surprising when we consider that firms tend to follow a strategy of searching for new markets to sell their production. In this case, it may be more common that firms choose to export or to establish partnerships in external markets, rather than implementing FDI. In addition, the search for markets presupposes that firms will essentially trade the same product, or a similar product, which would require a similar CAGE institutional profile between Brazil and the FDI host market. 


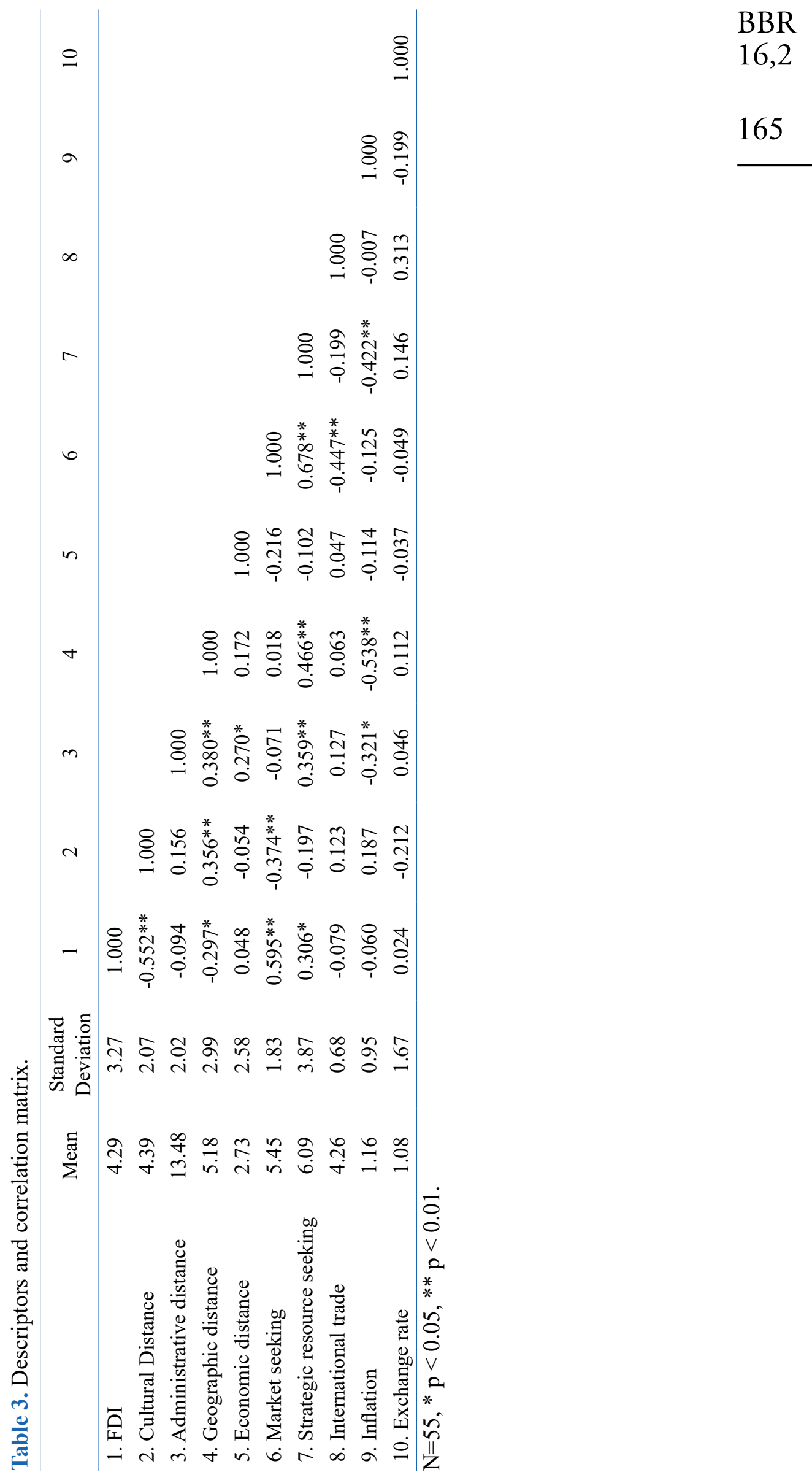




BBR
16,2
166

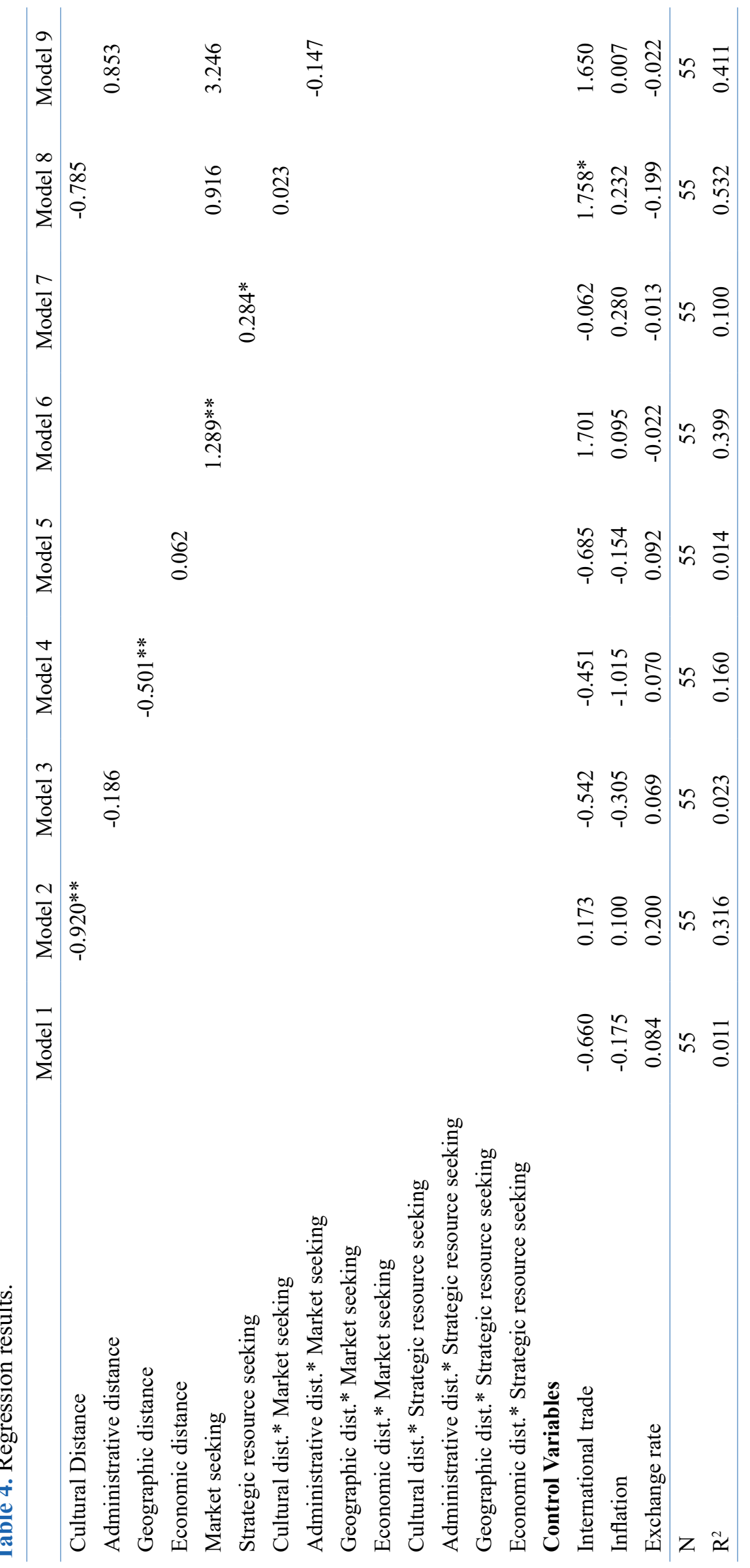




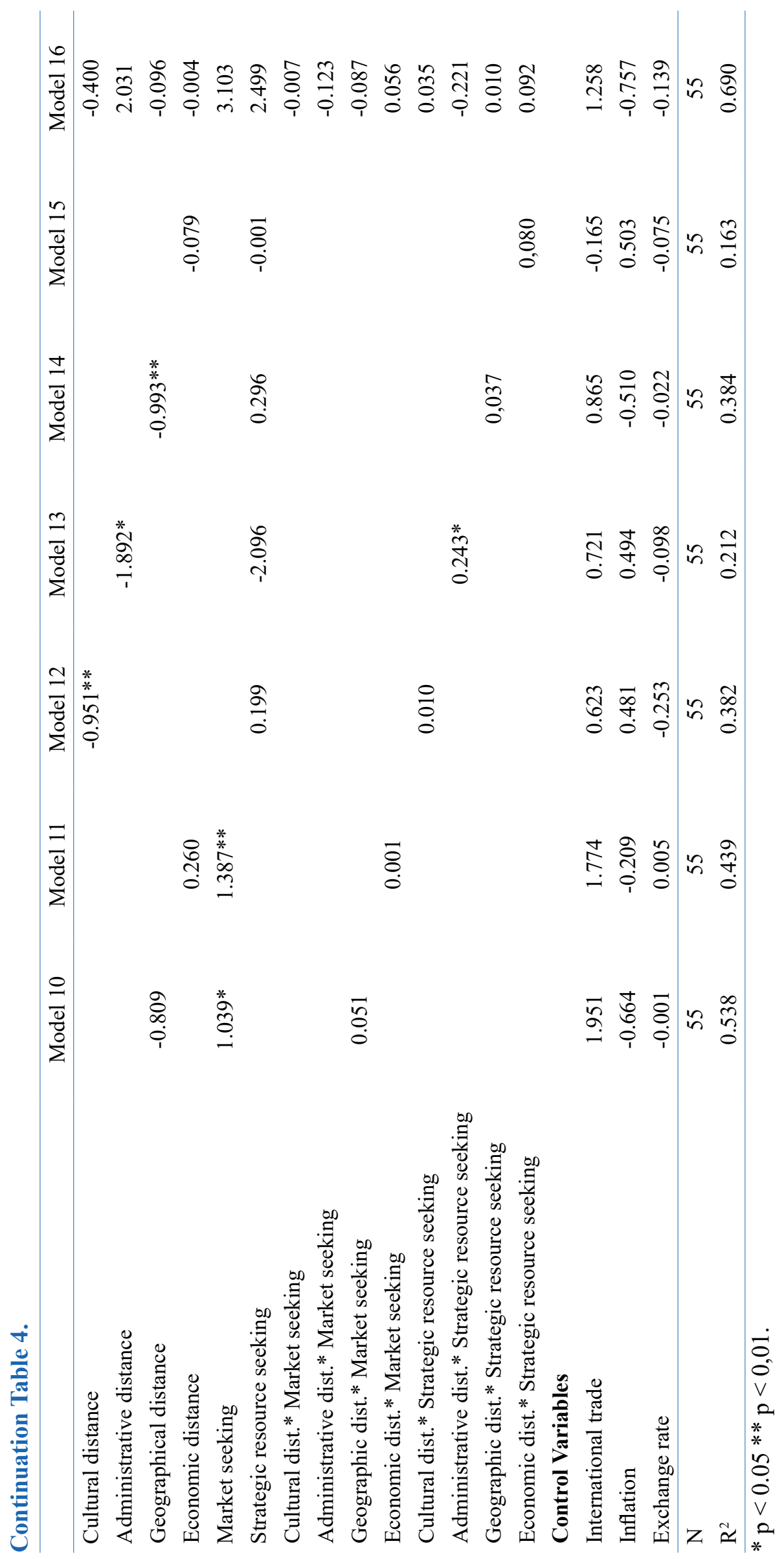

BBR

16,2

167 
BBR

16,2

168
Models 12 to 15 test hypothesis 5 on the moderating effect of the strategic resource seeking motivation on the relation between CAGE distances and the Brazilian FDI. The tests only confirm a positive and significant coefficient for the Administrative distance $(\beta=0.243, p<0.05)$, confirming only partially $\mathrm{H} 5$. The variable administrative distance (GHEMAWAT, 2014) encompasses differences in factors such as colonial ties, lack of political and monetary association, political hostility, government policy and institutional weakness.

The complete model (model 16) includes all variables and shows no significant relationship to CAGE distances and strategic motivations. This is interesting especially considering there is no multicollinearity in the data, but it can show that institutional dimensions and distances are not absolutely and mutually exclusive. In fact, it is simple to understand that the distances between countries in one dimension possibly have a high level of relation in other dimensions. For instance, geographically more distant countries tend to have more dissimilar cultures and their own administrative systems will tend to evolve differently. Similarly, and following March's (1991) constructs of exploitation and exploration, it is likely that firms pursue a mix of motivations when entering foreign markets. That is, a dominant motivation can coexist with motivations, or objectives, that are somewhat more secondary.

An analysis of the data reveals that in the period 2010-12, the outflows of Brazilian FDI was directed to large and growing markets (market seeking) and attracted by strategic resources. With respect to the interactions between distance, motivations and FDI, only the search for strategic resources has a positive influence on the relationship between administrative distance and FDI, demonstrating that FDI flows are less sensitive to the impact of administrative distance when there is a strategic resource seeking motivation that underlies investment decisions.

The analysis of the Brazilian FDI destinations reveals greater concentration in the more developed countries ( $33 \%$ of the sample), while neighboring countries, such as Argentina and Chile, $16 \%$ and other emerging countries without geographical borders with Brazil, $51 \%$. That is, about $84 \%$ of the Brazilian FDI is oriented to countries without geographical borders with Brazil. These evidences are relevant because they contrast with previous studies that noted a significant effect of geographical distance as a barrier to internationalization (e.g., BERRY; GUÍLLEN; ZHOU, 2010). Similarly, we note that the main destinations of Brazilian FDI (Austria, the Netherlands, the USA, Spain and Denmark) at least potentially leading to more economically developed countries. These countries of destination have more stable and efficient institutions reducing transaction risks and costs.

\section{DISCUSSION AND FINAL CONSIDERATIONS}

This study responds to the growing interest in investigating the role of institutions and the strategic motivations of firms in conducting international business. These implications may be especially relevant when analyzing emerging and Latin American economies, given, on the one hand, institutional inefficiencies (DUNNING, 2006; CUERVO-CAZURRA, 2015) and, on the other hand, the relatively small international experience of multilatinas (FLEURY et al., 2013). While the existing literature (see, for example, BUCKLEY, et al. 2007) has scrutinized the impact of many variables on FDI flows, such as: motivation for searching for markets and searching for strategic assets, political risks, institutional distance, business environment, and flow of exports/imports, our results allow for an understanding of how institutional distances (here evaluated in the four large CAGE dimensions) influences the 
outflows of FDI and how the strategic motivations for FDI can influence the predictable negative effect of higher levels of institutional differences between countries on FDI flows.

The study results show that the cultural distance has a negative impact on the outflows of Brazilian FDI, corroborating previous studies in other national contexts (KOGUT; SINGH, 1988; CHILD; RODRIGUES, 2005). The results are consistent with the study by Dikova and Van Witteloostuijn (2007) which focuses on firms from emerging economies. Using a perspective based on the theory of transaction costs, greater distance increases the uncertainty and risks of investments (HARZING, 2002).

The analysis of the strategic motivations reveals that the Brazilian FDI seeks large markets and strategic resources. Using the typology by Dunning (1993), but at the level of national investment as a whole, we have identified that the two primary motivations - market seeking and strategic resource seeking - are effectively relevant drivers of FDI. Scale gains and the technological and knowledge upgrade that FDI allows helps to build competitive capacity at the international level. Given that Brazil is in itself a large market, the motivation to search for markets may be the result of domestic institutional inefficiencies (e.g., infrastructure). In addition, the low purchasing power of the population imposes restrictions on the growth of firms. Thus, internationalization can be an escape (CUERVO-CAZURRA et al., 2015; CUERVO-CAZURRA, 2016) from the difficulties of accessing the domestic market. Regarding the strategic motivation to search for strategic resources, multinational firms earn, through FDI, specific assets (strategic resource seeking). Therefore, they take advantage of the market position of the acquired company to have access to intangible resources.

In addition to the contribution already pointed to the stock of knowledge applied to Brazil, the primary focus of this study where its contribution lies is in the contrast between the Institution-Based View and the strategic choices of firms, and their interactions, for internationalization through FDI. Because academic debate has focused on institutional aspects in more recent years, it is important to put the business strategies back into the equation. As strategies are not formulated in an isolated world it is foreseeable that there are multiple interactions between the strategies (already conditioned by the resources and advantages held) and external institutional elements (multifaceted). Perhaps this is the contrast, at least in part, between an institution-based view and a resource-based view. From a resource-based view, it is important to analyze whether the internationalization of Brazilian firms is based on the search for new resources - in a move of exploration in the typology by March (1991) - or in the possession and exploitation of pre-existing domestic assets to be exploited abroad - which would correspond to exploitation. In any case, it is still possible that the pressures to explore and prosper coexist.

It is still interesting how Brazilian firms react to institutional differences. The traditional response of the theory would be that they will tend to avoid territories with more dissimilar institutions, institutionally less sophisticated environments than its domestic market, and to seek partnerships as a way to better learn about the institutional framework in a country of destination. Evidence, however, indicates that Brazilian multinationals invest in other countries as the main mode of expansion and resort little to partnerships where they do not have at least control of operations (PINTO et al., 2017). Thus, there is still much to be understood about how Brazilian firms react to institutional differences in their internationalization and how the selection of markets can be driven by the motivations. Alternatively, how the entry form fits the institutional characteristics of the country of destination. 


\subsection{LIMITATIONS AND SUGgESTIONS FOR FUTURE RESEARCH}

This study has limitations. We did not intend to generate an exhaustive model of all the institutional differences nor of all the strategic motivations that may underlie the realization of FDI. There are other determinants at the level of firms, industries and countries that can be considered in future research because of their impact in the realization of FDI, in contrast to the adoption of other modes of entry, and the choice of countries to invest. Relevant extensions may also include extending the study to other Latin American countries. As noted by Cuervo-Cazurra (2009), the Latin American context is still little explored despite the theoretical contribution potential that it contains.

Another relevant limitation is that we use aggregated country data. Ideally, the motivations would be evaluated at the individual level of each company, but we deal with the known lack of data on Brazilian firms. Nevertheless, aggregate analyzes allow for some inferences that can be better analyzed by conducting questionnaires and interviews, for example. A more disaggregated analysis at the industry level would better fit the CAGE approach by Ghemawat (2001) which mentions industries or products that are specifically affected by long institutional distances.

Finally, an element that deserves to be highlighted is the adoption of public policies to foster FDI. In this regard, more studies are needed examining the real impact of policies, for example, BNDES, on the internationalization and on the subsequent leverage of competences in the domestic market that are induced by firms that are internationalized.

\section{REFERENCES}

ARTIGE, L.; NICOLINI, R. Evidence on the determinants of foreign direct investment:The case of three European regions. Unitat de Fonaments de l'Anàlisi Econòmica (UAB) and Institut d'Anàlisi Econòmica (CSIC) UFAE and IAE Working Papers, n..655, 2005.

ALEKSYNSKA, M.; HAVRYLCHYK, O. FDI from the south: The role of institutional distance and natural resources, European Journal of Political Economy, v. 29(C), p. 38-53, 2013.

CEZAR, R; ESCOBAR, O. Institutional Distance and Foreign Direct Investment. Banque de France, n.579, 2015.

BCG. Redefining global competitive dynamics. Boston, MA: The Boston Consulting Group, 2014.

BÉNASSY-QUÉRÉ, A.; COUPET, M.; MAYER T. Institutional Determinants of Foreign Direct Investment. The World Economy, v. 30, n.5, p. 764-782, 2007.

BERRY, H.; GUILLEN, M.; ZHOU, N. An institutional approach to cross-national distance. Journal of International Business Studies, v. 41, n. 9, p. 1460-1480, 2010.

BLONINGEN, B. A review of the empirical literature on FDI determinants. International Atlantic Economic Society session, v. 33, n. 4, p. 383-403, 2005.

BROUTHERS, L.; O'DONNELL, E.; HADJIMARCOU, J. Generic product strategies for emerging market exports into triad nation markets: A mimetic isomorphism approach. Journal of Management Studies, v. 42, n. 1, p. 225-245, 2005.

BOISOT, M.; MEYER, M. Which way through the open door? Reflections on the internationalization of Chinese firms. Management and Organization Review, v. 4, n. 3, p. 349-365, 2008.

BUCKLEY, P.; CLEGG, L.; CROSS, A.; LIU, X.; VOSS H.; ZHENG, P. The determinants of Chinese outward foreign direct investment. Journal of International Business Studies, v. 38, n. 4, p. 499-518, 2007.

CAMPBELL, J.; EDEN, L.; MILLER, S. Multinationals and corporate social responsibility in host countries: Does distance matter? Journal of International Business Studies, v. 43, n. 1, p. 84-106, 2012.

CASANOVA, L. From multilatinas to global latinas: The new Latin American multinationals. Washington: Interamerican Development Bank, 2009a.

CASANOVA, L . Global latinas: Latin America's emerging multinationals. Londres, UK: Palgrave Macmillan, 2009b. 
CHILD, J.; RODRIGUEZ, S. The internationalization of Chinese firms: A case for theoretical extension? Management and Organization Review, v. 1, n. 3, p. 381-410, 2005.

CONTI, C.; PARENTE, R.; VASCONCELOS, F. When distance does not matter: Implications for Latin American multinationals. Journal of Business Research, v. 69, n. 6, p. 1980-1992, 2016.

CONTRACTOR, F.; LAHIRI, S.; ELANGO, B.; KUNDU, S. Institutional, cultural and industry related determinants of ownership choices in emerging market FDI acquisitions. International Business Review, v. 23, n. 5, p. 931-941, 2014.

CROSS, A.; VOSS, H. Chinese direct investments in the United Kingdom: An assessment of motivations and competiveness. Corporate Strategies in the New Asia. Alemanha: Universidade de Bremen, Working paper, 2008.

CUERVO-CAZURRA, A. The multinationalization of developing country MNEs: The case of multilatinas. Journal of International Management, v. 14, n. 2, p. 138-154, 2008.CUERVO-CAZURRA, A.; GENC, M. Transforming disadvantages into advantages: Developing country MNEs in the least developed countries. Journal of International Business Studies, v. 39, n. 6, p. 957-979, 2008.

CUERVO-CAZURRA, A.; DAU, L. Promarket reforms and firm profitability in developing countries. Academy of Management Journal, v. 52, n.6, p. 1348-1368, 2009.

CUERVO-CAZURRA, A. Multilatinas as sources of new research insights: The learning and escape drivers of international expansion. Journal of Business Research, v. 69, n. 6, p. 1963-1972, 2016.

CUERVO-CAZURRA, A.; NARULA, R.; UN, C. Internationalization motives: Sell more, buy better, upgrade and escape. Multinational Business Review, v. 23, p. 25-35, 2015.

CUERVO-CAZURRA, A. Multilatinas as a source of new theoretical insights: The learning and escape drivers of international expansion. Journal of Business Research, v. 69, n. 6, p. 1963-1972, 2016.

DAMANPOUR, F.; WALKER, R.; AVELLANEDA, C. Combinative effects of innovation types and organizational performance: A longitudinal study of service organizations. Journal of Management Studies, v. 46, n. 4, p. 650-675, 2009.

DENG, P. Why do Chinese firms tend to acquire strategic assets in international expansion? Journal of World Business, v. 44, n. 1, p. 74-84, 2009.

DIKOVA, D.; WITTELOOSTUIJIN, A. Foreign direct investment mode choice: Entry and establishment modes in transition economies. Journal of International Business Studies, v. 38, n. 6, p. 1013-1033, 2007.

DOW, D. A note on psychological distance and export market selection. Journal of International Marketing, v. 8, n. 1, p. 51-64, 2000.

DOW, D.; KARUNARATNA, A. Developing a multidimensional instrument to measure psychic distance stimuli. Journal of International Business Studies, v. 37,n. 5, p. 578-602, 2006.

DUNNING, J. The factors to attract FDI, multinational enterprises and the global economy, New York, NY: Addison-Wesley, 1993.

DUNNING, J. Towards a new paradigm of development: Implications for the determinants of international business. Transnational Corporations, v.15, n.1, p. 173-227, 2006.

DUNNING, J.; KIM, C.; PARK, D. Old wine in new bottles: A comparison of emerging-market TNCs today and developed-country TNCs thirty years ago. In: SAUVANT, K. The rise of transnational corporations from emerging markets: Threat or opportunity? Cheltenham, UK: Edward Elgar, 2008. ch. 8, p. 158180.

FERREIRA, M. Building and leveraging knowledge capabilities through cross-border acquisitions. In TALLMAN, S. New Generation in International Strategy, New York, NY: Edward Elgar Publishing, 2008. ch 9, p. 162-179.

FLEURY, A.; FLEURY, M.T.; BORINI, F. The Brazilian multinationals' approaches to innovation. Journal of International Management, v.19, n.3, p. 260-275, 2013.

GATIGNON, H.; ANDERSON, E. The multinational corporation's degree of control over foreign subsidiaries: An empirical test of a transaction cost explanation. Journal of Law, Economics \& Organization, v.4, n.2, p. 305-336, 1998.

GHEMAWAT, P. Distance still matters: The hard reality of global expansion, Harvard Business Review, v.79, n.8, p. 137-147, 2001.

GHEMAWAT, P. The forgotten strategy. Harvard Business Review, v.81, n.11, p. 76-84. 2003.

GHEMAWAT, P. CAGE comparator ${ }^{\text {TM }}$ - Analyze distances and differences between countries. Disponível em: <http://www.ghemawat.com/cage/, 2014>. Acesso em 02 fev. 2014. 
GOUVEA, R. The transnationalization of Brazil's software industry, Transnational Corporations Journal, v.16, n.1, p.145-164, 2007.

GUGLER, P.; BRUNNER, S. FDI effects on national competitiveness: A cluster approach. International Advances in Economic Research, v.13, n.3, p. 268-284, 2007.

HARZING, A. Acquisitions versus greenfield investments: International strategy and management of entry modes. Strategic Management Journal, v.23, n.3, p. 211-227, 2002.

HOFSTEDE, G. Cultural consequences: International differences in work related values. Beverly Hills, CA: Sage, 1980.

IMF. International Monetary Fund. Outward foreign direct investment and domestic investment: The case of developing countries. International Monetary Fund Working Paper, 2013.

IMF. International Monetary Fund. IMF Exchange rates. Disponível em: $<$ https://www.imf.org/external/np/ fin/ert/GUI/Pages/CountryDataBase.aspx. Acesso em: 02 ago. 2017.

JOHANSON, J.; VAHLNE, J.-E. The internationalization process of the firm: A model of knowledge development and increasing foreign market commitments. Journal of International Business Studies, v. 8, n. 1, p. 23-32, 1977.

KOGUT, B.; SINGH, H. The effect of national culture on the choice of entry mode. Journal of International Business Studies, v.19, n.3, p. 411-432, 1988.

KOSTOVA, T.; ZAHEER, S. Organizational legitimacy under conditions of complexity: The case of the multinational enterprise. Academy of Management Review, v.24, n.1, p. 64-81, 1999.

KOSTOVA, T.; ROTH, K. Adoption of an organizational practice by subsidiaries of multinational corporations: Institutional and relational effects. Academy of Management Journal, v.45, n.1, p. 215-233, 2002.

LUO, Y. TUNG, R. International expansion of emerging markets enterprise: a springboard perspective. Journal of International Business Studies, v.38, n.4, p. 481-198, 2007.

MAKINO, S.; LAU, C.-M.; YEH, R.-S. Asset-exploitation versus asset-seeking: Implications for location choice of foreign direct investment from newly industrialized economies. Journal of International Business Studies, v.33, n.3, p. 403-421, 2002.

$\mathrm{MARCH}$, J. Exploration and exploitation in organizational learning. Organization Science, v.2, n.1, p. 71-87, 1991.

MATHEWS, J. Dragon multinationals: New players in 21st century globalization. Asia Pacific Journal of Management, v.23, n.1, p. 5-27, 2006a.

MATHEWS, J. Response to Professors Dunning and Narula. Asia Pacific Journal of Management, v.23, n.2, p. 153-155, 2006b.

MEYER, J.; ROWAN, B. Institutionalized organizations: Formal structure as myth and ceremony. American Journal of Sociology, v.83, n.2, p. 340-363, 1977.

MEYER K.; ESTRIN S.; IONASCU, D. Institutional distance and international business strategies in emerging economies. William Davidson Institute, Escola de Negócios da Universidade de Michigan. Working Paper, 2004.

NETER, J.; WASSERMAN, W.; KUTNER, M. Applied linear statistical models, Homewood: Irwin, 1985.

NORTH, D. Institutions, institutional change and economic performance. Cambridge, MA: Cambridge University Press, 1990.

OTALORA, M.; CASANOVA, L. Resources and Internatiobalization Strategies: The case of Latin American Multinationals. INSEAD Working Paper, 2012.

PENG, M.; WANG, D.; JIANG, Y. An institution-based view of the international business strategy: A focus on emerging economies. Journal of International Business Studies, v. 39, n. 5, p. 920-936, 2008.

PINTO, C.; FERREIRA, M.; FALASTER, C.; FLEURY, M.T.; FLEURY, A. Ownership in cross-border acquisitions and the role of government support. Journal of World Business, v.52, n.4, p.533-545, 2017.

SALOMON, R.; WU, Z. Institutional distance and local isomorphism strategy. Journal of International Business Studies, v.43, n.4, p. 343-367, 2012

STAL, E.; CAMPANÁRIO, M. Empresas multinacionais de países emergentes: o crescimento das multilatinas. Economia Global e Gestão, Lisboa, v.15, n.1, p. 55-73, 2010.

TAYLOR, R. Globalization strategies of Chinese companies: Current developments and future prospects. Asian Business and Management, v.1, n.2, p. 209-225, 2002.

UNCTAD. Occasional note Outward FDI from Brazil: Poised to take off? Disponível em: $<$ http://www. unctad.org/org, 2004>. Acesso em: 22 dez. 2013. 
UNCTAD. World Investment Report. Nova Iorque e Geneva: United Nations Press, 2006.

UNCTAD. World Investment Report. Nova Iorque e Geneva: United Nations Press, 2012.

UNCTAD. Inward and outward foreign direct investment flows, annual, 1970-2012. Disponível em: $<$ http://unctadstat.unctad.org/TableViewer/tableView.aspx?ReportId=88>. Acesso em: 16 dez. 2013.

WITT, M.; LEWIN, A. Outward foreign direct investment as escape response to home country institutional constraints. Journal of International Business Studies, v. 38, n. 4, p. 579-594, 2007.

WIPO. World Intellectual Property Organization. Statistics on worldwide patent activity. Disponível em: $<$ http://www.wipo.int/ipstats/en/statistics/patents/wipo_pub_931.html\#a13>. Acesso em: 31 jan. 2013.

WORLD BANK. WDI - World Development indicators. Disponível em: <http:// http://data.worldbank.org/ data-catalog/world-development-indicators $>$. Acesso em: 27 nov. 2013.

XU, D.; SHENKAR, O. Institutional distance and the multinational enterprise. Academy of Management Review, v. 27, n. 4, p. 608-618, 2002.

YIU, D.; LAU, H.; BRUTON, G. International venturing by emerging economy firms: The effects of firm, home country networks, and corporate entrepreneurship. Journal of International Business Studies, v. 38 , n. 4, p. 519-540, 2007. 